\title{
ПЕДАГОГІКА ДОЗВІЛЛЯ - ДУХОВНІСТЬ, ІНТЕЛЕКТ, СТРАТЕГІЯ
}

\section{А. О. Денисенко}

к. пед. н., доцент, доцент кафедри історії педагогіки і порівняльної педагогіки, Харківський національний педагогічний університет імені Г. С. Сковороди

Освіта - запорука майбутнього країни; це банк збереження культури народу, національних цінностей (історії, традицій); це важіль примноження інтелектуального потенціалу держави (освіченості громадян, професійної майстерності майбутніх фахівців), це портал виховання громадянської самосвідомості й людських цінностей (патріотизму, моралі та ін.), розвитку людських здібностей (творчості, естетичного смаку, етикету та ін.).

Під час перебування дитини, молодої людини у навчально-виховних закладах (дитячий садок, школа, позашкільний заклад, заклади вищої освіти та ін.) освіта системно, послідовно, безперервно і фундаментально здійснює комплекс педагогічних завдань. Одне з важливих освітніх завдань - це створення умов (психологічних, педагогічних, соціальних, економічних тощо) для раціонального, доцільного, змістовного, багатоаспектного дозвілля молоді з метою розвитку, самореалізації й удосконалення загальних і специфічних здібностей особистості, її соціалізації, задоволення потреб та інтересів молоді країни й виховання Людини-Громадянина нової генерації.

Освітньо-виховна функція вищогонавчального закладу знаходиться у складній залежності від соціальних потреб, державного замовлення, самостійного пошуку університетом своєї особливої прогресивної освітньодержавної місії, яка увиразнюється у виховно-формуючому й освітньо-розвиваючому впливі на особистість студента (у виховні системі вищої школи) засобом педагогічно організованого середовища, зокрема, інфраструктурою університетського дозвілля.

Дозвілля - спеціалізована підсистема духовно-культурного життя суспільства, що функціонально об'єднує соціальні інститути, покликані забезпечити поширення духовно-культурних цінностей, їх активне творче освоєння людьми у сфері дозвілля з метою формування гармонійно розвиненої, творчо активної особистості, громадянина, індивідуума, фахівця.

Кожен освітній заклад має свою місію, візію, політику, мету, головні завдання і конкретні засоби їх виконання, спрямовані на розвиток упродовж перспективної програми діяльності конкретного закладу (кожні п’ять років). Головні завдання програми спрямовують й удосконалюють (упродовж визначеного терміну перспективного розвитку) шляхи ії виконання через навчальну, науково-дослідну й інноваційну, міжнародну та виховну діяльність університету. Виховна система (BC) освітніх закладів $\epsilon$ рушійною силою у формуванні людського капіталу підростаючого покоління.

ВС освітнього закладу — це сукупність елементів (виховних відносин, технологій управління навчально-виховним процесом, форм організації діяльності, засобів та методів навчання й виховання), які в цілісній спільності та взаємозв'язку створюють якісно психолого-педагогічні умови для розвитку та формування особистості.

ВС вищого освітнього педагогічного закладу включає в себе такий вагомий компонент, як «доцільно організоване» освітнє середовище (навчання, виховання, просвітництво, дослідницька та дозвіллєва діяльність), що має відповідати основним вимогам, серед яких:

- формувати у сучасної молоді соціально й особистісно значущі потреби, інтереси, запити та забезпечувати умови для їх задоволення відповідно до соціальних, культурних, моральних норм і загальнолюдських цінностей (формувати соціальну активність, стійку громадську позицію та відповідальність, здоровий спосіб життя, вміння вільно мислити та самоорганізовуватися в сучасних умовах тощо);

- створювати необхідні умови для самореалізації духовних сил особистості і соціальних спільнот;

- забезпечити відтворення соціокультурного, освітнього, інтелектуального, творчого потенціалу молодої людини;

- примножувати моральні, культурні, наукові цінності та досягнення суспільства;

- сприяти професійному зростанню майбутнього спеціаліста, формуванню фахової майстерності.

Концепція ВС закладу вищої педагогічної освіти обумовлює: підвищення ролі закладу вищої освіти щодо виховання майбутніх педагогів та набуття інтелектуального, духовного, виховного потенціалу системи освіти в цілому; творчу співпрацю та взаємодію професорсько-викладацького складу та студентської молоді; організацію кураторами (наставниками, т'юторами) позааудиторної роботи, дозвіллєвої діяльності студентів з різних напрямів роботи (соціалізація особистості, залучення до культурних цінностей, формування людських та духовних цінностей, освоєння професійної майстерності та ін.); узагальнення та розповсюдження досвіду 
виховної роботи (організації дозвіллєвої діяльності); здійснення дослідницьких проектів (вивчення та дослідження виховних технологій, сутності педагогіки дозвілля й особливостей дозвіллєвої діяльності), модернізація й удосконалення виховної системи ВНЗ та ін.

Забезпечити цілісне виховне середовище можливо шляхом організації такої культурно-дозвіллєвої (не примусової, доцільної, змістовної) діяльності, яка забезпечить зацікавленість студентів, активну життєву і громадську позицію сучасної молодої людини, інтелектуальний і творчий розвиток майбутнього вчителя, професійне зростання, самовизначення та самовдосконалення майбутнього фахівця.

Слід зазначити, що дозвіллєва діяльність пов'язана з духовним світом і має таку закономірність, як дзеркальність і універсальність. Уся дозвільна діяльність перебігає у межах вільного часу, визначеного культурноосвітнього простору та обраного змісту творчості. Вони тісно пов'язані між собою і формують смаки, уподобання людей різного віку, задовольняють їхні інтереси, пристрасті, реалізують духовні і фізичні сили.

Дозвілля приваблює особистість своєю нерегламентованістю та добровільністю вибору його різних форм, демократичністю, емоційною забарвленістю, можливістю поєднати фізичну й інтелектуальну діяльність, творчу та споглядальну, виробничу й ігрову.

У молодіжному мікросоціумі вільний час перетворюється у засіб активного розвитку, майданчик самовираження, специфічну форму культурно-просвітницького завантаження молоді. Відпочинок, дозвілля, розваги, як і праця, є невід'ємними складовими життєдіяльності сучасної молодої людини. Розважаючись, людина задовольняє свої духовні та інтелектуальні потреби, оцінює свої можливості. Тому сьогодення вимагає від педагогіки дозвілля і молодіжної політики держави взагалі чітко зрозумілої, змістовно-доцільної стратегії в організації дозвіллєвої діяльності молоді.

Важливо при організації дозвіллєвої діяльності студентства враховувати, що на вибір дозвілля (активного, пасивного, цілеспрямовано активного) впливають вікові, психологічні та статеві особливості, індивідуальні інтереси, потреби та захоплення, суспільне становище, сімейні умови і фізичний стан, дохід, менталітет, освіта, інтелектуальна мобільність сучасної молоді, середовище особистісного спілкування (сімейне, позасімейне, шкільне, позашкільне, виробничо-трудове, міжнаціональне) та не особисте спілкування (ЗМІ, природа, мистецтво, книга та ін.), тимчасове захоплення тощо.

Стратегія педагогіки дозвілля сьогодення в Україні - надважливий аспект вирішення багатьох проблем суспільства: булінг, молодіжна злочинність, Інтернет та комп'ютерна залежність, інформаційна агресія, духовний занепад, асоціальна поведінка молодої людини тощо. Особливого значення це питання набуває для студентства педагогічних закладів - суб’єктів подальших реформ, змін, як в освіті, так і в країні в цілому. Володіння майбутніми вчителями педагогікою дозвілля надасть можливість виправляти, корегувати, попереджати «педагогічний колапс» сьогодення. Саме вчителю необхідно використовувати власний творчий та інтелектуальний потенціал з метою розширення зони духовного і морального впливу на різні категорії громадян нашої країни.

Безперечно, проблема організації культурно-дозвіллєвої діяльності майбутніх педагогів, заслуговує на пильну увагу ще й тому, що не кожен студент уміє організовувати своє власне дозвілля з користю, особливо з метою особистісно-професійного зростання. У зв'язку з цим перед ВС освітнього закладу постає питання чіткої педагогічної організації виховної позааудиторної роботи студентів, спрямованої на здобуття досвіду дозвіллєвої діяльності, навчання та впровадження різних напрямів, форм, видів дозвілля.

У наукових розвідках учені (І. Бєлецька, О. Бойко, В. В. Бочелюк, В. Й. Бочелюк, А. Воловик, В. Воловик, І. Грінішина, І. Ісаєва, Т. Ковальчук, Л. Кожевнікова, Н. Котєльнікова, Н. Максимовська, О. Недзвецька, Г. Олійник, I. Петрова, С. Пішун, С. Савчук, I. Сидор, О. Тадля, І. Шевчук та інші) опікуються проблемою організації дозвілля студентської молоді, дають визначення дефініціям «вільний час», «педагогіка дозвілля», «дозвіллєва діяльність» та розглядають специфіку, види, напрями, функції (розвиваюча, комунікативна, рекреативнооздоровча, культурно-творча, гедоністична) студентського дозвілля, аналізують форми, сфери, індустрію дозвілля та визначають навчально-виховний вплив на особистість сучасної молодої людини.

Водночас сьогодні вітчизняна педагогіка дозвілля, дещо абстрагована від політики й ідеології, хоча і $\epsilon$ великою спадщиною теоретичних пошуків і практичного досвіду. Зараз накопичений величезний досвід з методики масової освітньо-виховної роботи, організації ії різноманітних форм, методики проведення й організації свят і видовищних заходів, постановок сценічних композицій, диспутів, наочної пропаганди, клубних вечорів, постановки літературних і музичних композицій, театралізації, екскурсій, технології організації виховного процесу в дозвільних, творчих об'єднаннях, організації спільної діяльності освітніх й позашкільних закладів і закладів дозвілля.

Слід зазначити, що зараз у педагогіці й молодіжній (інформаційній, соціальній) політиці держави має буть нагальним питанням (надважливим акцентом) - «поглибити» в освіті й суспільстві патріотичне виховання 
громадян України. Звідси необхідність посилити увагу щодо впровадження у педагогічний процес освітніх закладів ефективних форм дозвілля, методів, прийомів, різних виховних заходів щодо збереження територіальної цілісності країни, примноження національних і культурних цінностей України, виховання громадянської свідомості, справжнього патріота своєї країни. Пошук ефективних шляхів вирішення цієї освітньої проблеми намітив нішу у навчально-виховному процесі вищих освітніх педагогічних закладах.

Сьогодні визначну роль у вирішенні багатьох педагогічних проблем покладаємо і на навчальну дисципліну «Педагогіка дозвілля», яка є в учбових планах деяких вищих освітніх закладів України. Але незаперечним $є$ факт того, що цієї дисципліни дійсно бракує у багатьох педагогічних закладах, які $є$ освітнім фундаментом, джерелом збереження національної культури, інтелекту, прищеплення особистості духовності, моральності, становлення професійної і громадянської свідомості. Безумовно, у певних педагогічних дисциплінах є окремі розділи, де розглядаються деякі питання виховної роботи: методи, форми позааудиторної роботи, функції, напрями виховної діяльності, але відповідних знань, умінь і навичок дозвіллєвої діяльності можна здобути шляхом грунтовного вивчення теоретичних основ «Дозвіллєзнавства» та практичних «Педагогіки дозвілля», а також шляхом упровадження отриманих знань у практичну діяльність студентів (педагогічна практика, власний вільний час). Це дозволить здійснювати виховний та освітній процес шляхом цілеспрямованої планомірної і систематичної організації дозвільної діяльності шляхом переведення іiї на більш високий рівень розвитку.

Дозвіллєзнавство - це галузь науки, яка вивчає життєдіяльність, відносини й організацію людей у сфері вільного часу.

Педагогіка дозвілля - це наука про вплив дозвіллєвої діяльності на соціально-культурне середовище, духовний світ іiї суб’єктів і об’єктів — творців і споживачів культурних благ і цінностей з метою підвищення їх дозвіллєвої кваліфікації.

Мета педагогіки дозвілля - сприяти гармонійному розвитку особистості, реалізації ії здібностей і можливостей у сфері вільного часу, формувати культуру дозвілля, мотивувати особистості на пізнавальне та змістовне дозвілля, розвивати позитивний виховний дозвіллєвий потенціал, попередження «кризи моралі» сучасної молоді, стимулювання дозвіллєвої активності. Щоб бути повноцінною теоретичною і практичною дисципліною, педагогіка дозвілля повинна враховувати педагогічний досвід, історичну спадщину виховної, дозвіллєвої діяльності суспільства та впроваджувати інновації дозвіллєвої сфери, території, індустрії.

Об’єктами педагогіки дозвілля виступають люди різного віку — від дітей дошкільного віку до людей віку поважного, а також явища соціо-культурної дійсності (культурно-просвітницькі блага, творчість, соціальна та громадська активність), які обумовлюють розвиток особистості-індивіда в процесі цілеспрямованої, змістовної дозвіллєвої діяльності.

Єдність загальнотеоретичної, прогностичної та практичної (розвиваюча, комунікативна, рекреативнооздоровча, культурно-мистецька, гедоністична) функцій педагогіки дозвілля дозволяє найбільш повно виконувати завдання педагогічного процесу в різних соціальних середовищах, здійснювати стратегію педагогічних закладів - виховання гармонійно розвиненої особистості, індивідууму, громадянина, фахівця.

Як галузь педагогічної та культурологічної наук педагогіка дозвілля відрізняється множинністю принципів (педагогізація навколишнього соціально-культурного середовища, особистісний підхід, наступність, облік культурного різноманіття взаємодіючих суб’єктів і об'єктів, орієнтація на культурно-ціннісні відносини й організацію культуротворчості, самодіяльності) і $€$ носієм людської культури, освіченості, духовності та системним джерелом отримання знань, соціального досвіду, ціннісних орієнтацій.

Основним структурним елементом дозвіллєвої діяльності є мотив - потреба особистості в самому процесі дозвіллєвої діяльності (у різних їі формах і форматах), яка продиктована особистими потребами й інтересами людини, а не виникла під тиском зовнішніх обставин. Але слід зауважити, що в педагогічних освітніх закладах, окрім організації студентського дозвілля, $є$ надважлива освітня задача — навчити майбутнього вчителя спрямовувати погляд підростаючого покоління на «розумний» вибір свого дозвілля (відпочинок, розваги, споживання культурних благ тощо) з метою розвитку, виховання особистості, індивідууму, фахівця, громадянина, маючи на меті попередити «руйнацію» особистості українця, нації в цілому.

Оволодіння теорією і методикою педагогічної організації дозвільної діяльності повинно відбутися під час педагогічного процесу в університеті:

- вивчення навчальних дисциплін «Педагогіка дозвілля», «Дозвіллєзнавство» тощо (оволодіння теоретичним і практичним пластом дозвіллєвої культури);

- педагогічна практика (упровадження дозвіллєвих технологій), 
• участь у позааудиторній роботі (здобуття дозвіллєвої практики);

- залучення до гурткової роботи (набуття дозвіллєвого потенціалу);

- організація життєдіяльності в гуртожитку (стимулювання дозвіллєвої активності);

- дослідницька діяльність (апробація нових виховних, дозвіллєвих технологій).

У подальшому набутий власний досвід організації дозвілля (ігрового, музичного, танцювального, театрального, читацького, екранного та ін.), майбутні педагоги повинні вміти спроектувати на будь-яку аудиторію. Тому під час навчання студентів у педагогічному університеті слід забезпечити таку сферу, атмосферу, індустрію дозвілля, яка позитивно впливає на внутрішнє стимулювання до дозвіллєвої активності особистості майбутнього фахівця, до саморозвитку і самовдосконалення в цій галузі.

У спектрі дозвілля виділяють багато видів дозвіллєвої діяльності: відпочинок, розваги, свята, конкурси, споглядання, гуртки, секції, об'єднання, ресурс яких повинен розвивати інтелектуальні і творчі здібності, логічне та творче мислення у студентів, формувати культуру розумової праці, виробляти уміння самостійно здобувати знання, збагачувати світогляд і застосовувати набутий багаж знань, умінь і навичок на практиці засобами дозвілля.

Усі форми організації дозвілля тісно взаємопов'язані між собою, доповнюють одна одну, мають самостійне теоретико-методичне значення і створюють цілісну систему дозвіллєвої діяльності, спрямованої на вирішення концептуальних завдань національної програми виховання підростаючого покоління та відповідають стратегії молодіжної політики України.

Велику привабливість у сучасної молоді мають розважальні форми дозвілля, але головна задача педагогічних університетів - ознайомити майбутніх педагогів з усіма різновидами, формами дозвіллєвої діяльності (квести, диспути, тематичні вечори, концерти, КВК, фестивалі, мандрівки-екскурсії, кураторські годинибесіди, конкурси-огляди, змагання, олімпіади, конференції, круглі столи, форуми-семінари, виставки та ін.), які б сприяли: формуванню у молоді високого рівня духовності, освіченості, культури і почуттів, об'єктивного і наукового пізнання світу, інтелектуальної мобільності; розвитку професійної готовності засвоювати, аналізувати нову інформацію, робити висновки, приймати відповідальні рішення; вихованню дозвіллєвої культури.

Отже, педагогіка дозвілля - платформа формування інтелектуального, духовного та професійного зростання, громадянської свідомості, власної гідності, виховання віри у свої сили, реалізації бажання власною працею досягти кращого життя, а не пасивно очікувати його.

Тому у вищих педагогічних навчальних закладах для отримання позитивних результатів навчально-виховного процесу, для здобуття комплексу професійних знань і розвитку комплексу професійних здібностей особистості та виховання загальної культури майбутнього вчителя необхідно створювати певні умови для організації дозвіллєвої діяльності студентів, від вивчення навчальних дисциплін («Педагогіка дозвілля») й організації власного вільного часу до педагогічно-доцільної, змістовно багатої дозвіллєвої діяльності.

\section{Література}

1. Бочелюк В. Й., Бочелюк В. В. Дозвіллєзнавство : навчальний посібник. К. : Центр навчальної літератури, 2006. $208 \mathrm{c}$.

2. Бойко О. П. Культура дозвілля: трансформації та перспективи розвитку у добу глобалізації : дис. ... д. філос. н. : 09.04.00. Х., 2011. $498 \mathrm{c}$.

3. Воловик А. Ф., Воловик В. А. Педагогіка дозвілля: підручник. Х. : ХДАК, 1999. 332 с.

4. Крестьянов В. П. Педагогика досуга: учебное пособие для студентов педагогических вузов и высших учебных заведений культуры. О. : ОГУ. 2010. 156 с.

5. Максимовська Н. О. Теоретичні і методичні засади соціально-педагогічної діяльності зі студентською молоддю у сфері дозвілля : дис. ... докт. пед. наук : 13.00.05. Х., 2015. 559 с.

6. Пішун С. Г. Проблеми формування духовності у сфері дозвілля студентів вищих навчальних закладів. Педагогічні науки. Т. : Вид-во ТПУ ім. В. Гнатюка. 2001. С. 228-235.

7. Шевчук І. Педагогічна сутність дозвілля та дозвіллєвої діяльності // Духовність особистості: методологія, теорія і практика. Вип. 1. 2014. С. 250-260. 